$\begin{aligned} & \text { 京都第二赤十字病院 } \text { 辻秀憲 } \\ & \text { 京都第一赤十字病院 } \text { 南郷武好 } \\ & \text { 京都府立医大病院 増田寿一 } \\ & \text { 京都桂病院 } \text { 西村正司 } \\ & \text { 国立京都病院 松山隆一 } \\ & \text { 国立福知山病院 村山 守 } \\ & \text { 大阪医大病院 植西信之 } \\ & \text { 滋賀成人病センター 小野武志 } \\ & \text { 滋賀医大病院 雄川恭行 } \\ & \text { 関西医大病院 西村茂樹 - 松田 茂 } \\ & \text { 住友病院 田中唐二 }\end{aligned}$

〔目的〕不整形照射野の線量補正を行うのに簡易的な 近似式が用いられている。そこでわれわれは，13施設の 各種治療装置を用い，不整形照射野とその近似式で求め た等価正方形照射野とによる実測値の一致度を検討した。

〔結果, 考察〕Linac 各種エネルギー, Co-60共に四隅 カット型は $4 \mathrm{~A} / \mathrm{L}$ 法で, T 字型は面積除去法にて補正し た方が，不整形照射野の実測値に近い值を示した．しか し四隅カット型では補正を行わない場合の誤差よりも大 きくなり，過大補正となる，今回用いた 2 通りの補正法 は，シールド方式との組合せによっては大きな誤差を生 じる。したがって各施設に㧈いては，補正式の精度を十 分確認した上で使用すべきである。

135. New type TLD $\operatorname{LizB}_{4} \mathrm{O}_{7}: \mathrm{Cu}$, In, Si の $100 \mathrm{~Gy}$ までの Linearity とその Glow curve

獨協医科大学病院放射線部

○沢 佳延・佐藤和久・小黑 清 加藤幸弘・石田 薰・坂本知志

〔目的〕 New type LBO : Cu，In，Si が10 Gy までに おいて linearity が良好であることは，第31回，関東・東

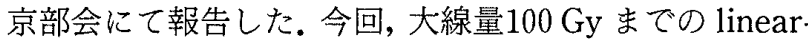
ity とその時のバラッキ，校正定数，大線量に沾ける glow curve を測定し，検討したので報告する，TLD素 子は極光ホウ酸りチウム,リーダーは Kyokko 2500を使 用した。

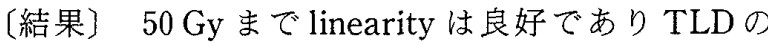
読取值の平均を $\mathrm{x}$ ，吸収線量を $\mathrm{y}$ とすると， $\mathrm{y}=26.7$ (土 4.9\%)x一定となった。バラツキは，2.95 mGy から 100 Gyに抢いて CV は7.38土0.64\%であった。また，glow curveの形状は，2つの peak も方線量変化による極 端な変化はなかった。

\section{6。F-CR を利用した線量分布}

国立がんセンター放射線治療部

○中里 啓・村上 勉・黑沢秀雄
関口雅幸・阿南充洋

$\mathrm{X}$ 線撮影技術の分野で増感紙，フィルム系に代わるセ ンサとして，輝尽性蛍光体を使った FCR システムが開 発され，X線写真がデジタル処理できるようになった。 今回，放射線治療に㧍ける高エネルギーX 線， ${ }^{60} \mathrm{Co} \gamma$ 線，および電子線について，FCR を用い，収録条件や階 調処理に着目し，線量とフィルム濃度に規則性のある相 関をもたせ，目で見て分かりやすい線量分布図を描くこ とができた。しかし，従来の線量計デー夕と若干の相違 がある。これは，本来診断用として開発されたイメージ ングペレートの線質依存性に依るものが大きく関与して いると思われる。この点について，今後検討していきた い.

\section{座長集約}

演題129は県内治療施設で保有する線量計に対して,卜 レサビリティを実施しその実態を明らかにし，線量評価 の精度を高めようとするものである。線量を校正された 線量計を用いて測ることが原則であるけれども，意外と 原則が踏れないのが実情のようである。演題134は，支部 内での治療施設が不整形照射野の補正をどのようにして 実施しているかを調べ，その近似式がはたして，その装 置エネルギーに適合しているのかを発表した，不整形照 射野のどの場所に測定点を設けるかは，一定の見解の無 いところであるが，照射野内の線量分布との関連につい て今一つ踏み込んだ解析が必要であろう。129，134席は グループ研究発表であり，今後ともに継続した活動報告 が寄せられることを期待したい.

演題130は熱中性子治療に先立って,ファントム実験を 行う上で適切な材質を熱中性子束分布から深部減弱率で 示した，理論計等と実測とで検討を進めているが，今後 は吸収線量に変換した深部線量百分率でファントム材の 特性を示せば役立つ研究となる。

演題131は直線加速器加らの光核中性子線の管理区域 境界に扔けるエネルギー・スペクトルを測定したもので ある，散乱㧍よび漏洩した X 線と（n，r）による即発 $\gamma$ 線とが同時に $\mathrm{Ge}$ 半導体検出器に入射するので，その弁 別が可能とするなら光核中性子線を分離して Sv 単位に 換算する手法も合わせて明らかとすべきであるう。

演題132は, 照射野内の散乱線と一次線とがどのような 割合で構成されているかを示そうとしたものである。指 頭形電離箱を使用すると，電離箱の形状による影響が小 照射野扔よび照射野の辺縁で著明となると考えられる。 さらに，従来から使われている SMR 法と比較したデー 夕の提供が望ましいので，次報を待ちたい。 
演題 133 は, 電離箱の収集効率に関する発表である.こ の測定では，パルス当りの線量が同じであることが前提 であり，電離電流一印加電圧曲線から飽和電流を得る印 加電圧を求めておくことも大切である．特殊なパルス発 生機構を有すると称するなら, 発表時に, パルス幅・パ ルス間隔などを図で示せば理解されやすい。電圧比がど のようになろうとも, 電離電流を集め切れない低い印加 電圧領域を設定することに疑問がある。

演題135は，TLDの線量值線性について検討した発表 である。この測定に使用するTLDは当然その再現性も 重要な因子であるが,あらかじめ各々の素子が絶対值(真 值）からどの程度離れているかを, 基準線源を使って調 べておき, 誤差の大きい素子を除外して扔くことが大切 である。

演題136は，FCR を線量分布採取に使用しようとする と，どのようになるかを検討したものである。この分布 を採取するのに用いるイメージング・プレートは，メー 力発表によれば線質依存性があるとされている。あえて 試みるならば，線質一発光量の関係を明確にすることに より校正する手段を得た上で分布の測定に用いるべきで あろう、特に電子線に利用する場合はファントム中での 電子線エネルギーと発光量との関係を十分に調べておく 必要があると考える. 発表時に, フィルム法と比較した データが示されると特性が理解されたのではないだるう か.

\section{$R 1-1$ 試料測定一1}

座長 河野敏彦（阪南中央病院）

\section{RIA における測定器の管理}

三井記念病院 RI センター

○田口逸夫・薄 英子・平塚千恵 埼玉県立小児医療センター放射線部 山本英明 三井記念病院放射線科

仙貫忠夫・木下幸次郎

5 本ディテクタ (DT) ガンマカウンタの性能を長期間 保持するための考案をした，校正を週 1 回行い，補正用 カウントとバックグラウンド (BG) 值よりカウンタ性能 と経年劣化を分析し，また光電子増倍管の電圧変動によ る振幅をみた。片対数グラフの ${ }^{125} \mathrm{I}$ 減衰直線傾斜の平均, $\mathrm{SD}, \mathrm{CV}$ より測定感度の変動が把握できた。ノイズは確 率紙法で平均と $\mathrm{SD}$ を求め $\mathrm{BG}$ 上昇傾向がつかめた。 5 項移動平均法で求めた補正係数の推移から点検による影 響が観察された．日常の測定器管理を励行することは当
然として, 購入・定期点検・故障修理後の点検等でメー 力側との情報交換の重要性が示唆された。

訂正 Fig. $1 \times 10$ (count) $\rightarrow \times 10^{5}$ (count)

\section{10 年間の $\mathrm{T}_{3}, \mathrm{~T}_{4}$ RIA 測定の評価}

神奈川県立成人病センター放射線治療科

○根本栄一郎・酒井聡子 滝沢俊一・山本洋一

〔目的〕 $\mathrm{T}_{3} ・ \mathrm{~T}_{4}$ の RIA 測定において，10年間の測定 デー夕を比較分析し，長期にわたる日常検查データの測 定精度に及ぼす影響について検討した。

〔結果〕標準曲線の各濃度における（Vは0.5〜4.0濃 度で $10 \%$ 以下であった。 $\mathrm{T}_{3}$ は $\mathrm{Bo} / \mathrm{T} \%$ も年々低下する 傾向にあった. $\mathrm{T}_{4}$ はほぼ一定した Bo/T \%であった。標 準曲線の $\mathrm{RERT}_{3}$ で平均 0.005 と良好であった。 $\mathrm{T}_{4}$ は $\mathrm{T}_{3}$ より安定していた。管理血清の $\mathrm{CV}$ は $\mathrm{T}_{3}$ で低中高濃度 の平均は $8.8,7.4,8.3 \%$ で, $\mathrm{T}_{4}$ は9.0, 6.8,7.4\%であ った. $\mathrm{T}_{3}$ と $\mathrm{T}_{4}$ の正常值は $\mathrm{T}_{3}$ で1.17〜 $1.25 て ゙$ 平均 1.22 とほぼ一定しており，ビーズ法がやや低い傾向にあった。 $\mathrm{T}_{4}$ は8.10〜8.99平均8.54と安定した值であった. 長年安 定したロットの品質, データの長期観察においては管理 血清の濃度の適切な決定が望まれる。

139. RIA キットの経時的安定性の検討一第 2 報一

岡山済生会総合病院放射線科

○宇佐美政栄・清水誠三

柴辻一成・小林有基

RIA キットの安定期間を検討し次の結果を得た１． 一般に標準物質の結合率は測定毎に低下するが，アマレ ックスTSHでは 5 回目の測定より高値に転じた. 2 . 血清值も標準物質の結合率とほぼ同じ経過をとるが， $\mathrm{SPACT}_{3} \mathrm{U}$, アマレックス $\mathrm{T}_{3} \mathrm{RIA}, \mathrm{SPAC} \mathrm{T}_{4} \mathrm{RIA}$, TSH 「第一」，リアグノスト TBG は $3 \sim 5$ 回目の測定より高 值に転じた．3．プール血清值（初回測定）の平均値士2 $\mathrm{SD}$ を基準にとると 3 回測定までは問題ない.4.初回 と最終回との相関は $\gamma=0.882$ 以上であった。

以上の結果より，3 分割測定までは信頼できる測定值 が得られると考える。

\section{0. 試薬ロットの変更に起因すると思われる測定值変 動の経験}

浜松医大放射線部 ○山田鎌太郎 浜松医大第二内科 真坂美智子

日常の精度管理は，デー夕を提供していく上で重要な 事柄となっている。われわれは，試薬ロットの変更によ ると思われる測定値の変動を経験したので報告する.

$\mathrm{T}_{4}$ 標準溶液のロット変更後, 管理血清の値が全濃度領 